\title{
Pengaruh Pengeringan terhadap Karakteristik Teh Herbal Celup Rimpang Temu Putih (Curcuma zedoaria Rosc.)
}

\section{The Effect of Drying On The Characteristics of Herbal Tea Bag Zedoary Rhizome (Curcuma zedoaria Rosc.)}

\author{
Risti Komariah $^{1}$, L.P. Trisna Darmayanti ${ }^{1}{ }^{*}$, N.M. Indri Hapsari Arihantana ${ }^{1}$ \\ Program Studi Teknologi Pangan, Fakultas Teknologi Pertanian, \\ Universitas Udayana, Kampus Bukit Jimbaran, Badung-Bali \\ Penulis korespondensi: L.P. Trisna Darmayanti, Email: trisnadarmayanti@unud.ac.id
}

\begin{abstract}
The purpose of this research was to find out the effect of drying on the characteristics of zedoary rhizome herbal tea bag (Curcuma zedoaria Rosc.) and to determine of drying that able to produce zedoary rhizome herbal tea bag with the best characteristics. The Completely Randomized Design (CRD) was used in this research with four drying treatments such as, drying using an oven at $50 \mathrm{oC}$ for 24 hours, drying using sunlight at $\pm 40 \mathrm{oC}$ for three days, drying using room temperature or dry wind at $\pm 26 \mathrm{oC}$ for six days, and drying by roasting at $\pm 50 \mathrm{oC}$ for 45 minutes. All of the drying were repeated four times to obtain 16 units of experiment. The analysis of variance (ANOVA) used to get data and if the drying had a significant effect, it was followed by the Duncan Multiple Range Test. The results showed that drying had a significant effect $(\mathrm{P}<0,01)$ on total curcuminoids, total phenols, total flavonoids, and sensory analysis of colour (scoring test). Drying using room temperature or dry wind had the best characteristic of zedoary rhizome herbal tea bag with content: total curcuminoid of 29,10 mg CE / g, total phenol of 167,51 mg GAE / g, and total flavonoid of $41,47 \mathrm{mg} \mathrm{QE} / \mathrm{g}$. The characteristics of the brewed water of zedoary rhizome herbal tea bag were dark yellow color and liked, the flavour distinctive of herbal tea zedoary rhizome and liked, the taste was bitter and usual, and overall acceptance was usual.
\end{abstract}

Keywords : zedoary rhizome, characteristics of herbal tea, drying method.

\section{PENDAHULUAN}

Temu putih (Curcuma zedoaria

Rosc.) merupakan tumbuhan dari suku temu (Zingiberaceae) yang telah lama digunakan dalam pengobatan tradisional atau herbal. Tanaman ini di Indonesia banyak dijumpai di daerah Sumatera dan Jawa, khususnya di daerah dengan ketinggian sampai $1.000 \mathrm{~m}$ dpl (Windono dan Nani, 2002). Komponen utama yang berkhasiat dalam rimpang temu putih adalah kurkumin, flavonoid, polifenol, serta minyak atsiri (Liang et al., 1995). Rimpang temu putih mengandung minyak atsiri yang terdiri dari monoterpen dan berkhasiat sebagai antineoplastic (antikanker). Beberapa manfaat dari tanaman ini adalah sebagai obat gangguan perut seperti mual, sebah, sakit perut dan diare. Dengan kandungan komponen dan manfaat yang baik untuk kesehatan tubuh, sangat disayangkan jika pemanfaatan rimpang temu putih oleh masyarakat umum hanya dikonsumsi dalam bentuk jamu segar, maupun sebagai bahan tambahan makanan. Dalam penelitian ini dilakukan usaha diversifikasi pangan terhadap rimpang temu 
putih dengan cara mengolahnya menjadi teh herbal. Rimpang temu putih segar akan dikeringkan kemudian di giling menjadi bubuk dan dikemas ke dalam kantong teh untuk memudahkan cara mengkonsumsi dan cara penyimpananya.

Teh herbal merupakan istilah umum yang digunakan untuk minuman berbahan baku tanaman seperti akar, bunga, batang dan daun yang bukan berasal dari tanaman teh Camellia sinensis (Yudana, 2004). Pada pengolahan teh herbal, pengeringan merupakan salah satu proses yang berpengaruh dalam menentukan produk dari segi warna, aroma, rasa, serta senyawa aktif yang terkandung di dalam bahan.

Terdapat dua metode pengeringan yang umum dilakukan oleh masyarakat adalah pengeringan secara moderen dan secara tradisional. Pengeringan secara moderen contohnya adalah menggunakan alat pengering berupa oven, namun memiliki biaya lebih tinggi dalam penggunaanya sehingga beberapa masyarakat memilih cara pengeringan secara tradisional contohnya dengan cara penjemuran dibawah sinar matahari, serta penyagraian. Berdasarkan penelitian Kencana (2015), pengeringan teh herbal dapat dikeringkan pada suhu $30^{\circ} \mathrm{C}-$ $90^{\circ} \mathrm{C}$, namun suhu yang menghasilkan teh herbal terbaik adalah tidak melebihi $60^{\circ} \mathrm{C}$.

Menurut penelitian Cesarika et al., (2018) mengenai pengeringan pada rimpang temulawak, temu giring, dan kunyit, menunjukkan bahwa pengeringan menggunakan oven dengan suhu $50^{\circ} \mathrm{C}$ menghasilkan karakteristik terbaik dibandingkan dengan pengeringan menggunakan sinar matahari. Setyani dan Astuti, (2013) dalam penelitiannya mengenai perbandingan rendemen minyak atsiri rimpang temulawak menyatakan bahwa metode pengeringan temulawak dengan cara di angin-anginkan menghasilkan nilai rata-rata rendemen tertinggi dibandingkan dengan pengeringan menggunakan oven dan sinar matahari.

Tujuan penelitian ini adalah untuk mengetahui pengaruh perlakuan pengeringan terhadap karakteristik teh herbal temu putih, serta untuk mengetahui perlakuan pengeringan yang mampu menghasilkan teh terbal temu putih dengan karakteristik terbaik.

\section{METODE PENELITIAN}

\section{Tempat dan Waktu Penelitian}

Penelitian ini dilaksanakan di Laboratorium Pengolahan Pangan dan Laboratorium Analis Pangan Program Studi Ilmu dan Teknologi Pangan Fakultas Teknologi Pertanian Universitas Udayana. Waktu penelitian ini berlangsung dari bulan Desember 2019 sampai bulan Februari 2020.

\section{Bahan dan Alat}

Bahan yang digunakan dalam penelitian ini terdiri dari bahan baku dan bahan kimia. Bahan baku yang digunakan adalah rimpang temu putih segar yang diperoleh dari petani temu putih di Desa 
Peninjoan, Bangli dengan usia panen kurang lebih 9 bulan. Bahan kimia yang digunakan adalah aquadest, etanol 95\%, standar kuersetin, standar asam galat, standar curcumin, reagen Folin-Ciocalteu, $\mathrm{Na}_{2} \mathrm{CO}_{3}$ $5 \%, \mathrm{NaNO}_{2} 5 \%, \mathrm{NaOH} 1 \mathrm{M}, \mathrm{NaOH} 5 \%$, $\mathrm{AlCl}_{3} 10 \%$, eter, serbuk magnesium, $\mathrm{HCl}$ pekat, $\mathrm{FeCl}_{3} 5 \%$, aluminium foil, kertas label, dan kertas saring Whatman no 1.

Alat yang digunakan dalam penelitian ini yaitu kompor, kuas, ayakan ukuran 40 mesh, gelas ukur (Pyrex), labu Erlenmeyer (Pyrex), labu ukur (Pyrex), gelas beaker (Pyrex), spektrofotometer (Genesys 10S UV-Vis), timbangan analitik (Shimadzu ATY224), kertas Whatman No. 1, vortex, panci, stopwatch, thermometer, blender (Panasonic), loyang, oven, tabung reaksi, rak tabung, pipet volume, pipet mikro, pipet tetes, waterbath, spatula, corong kaca, corong plastik, dan rotary shaker.

\section{Rancangan Percobaan}

Rancangan yang digunakan pada penelitian ini adalah Rancangan Acak Lengkap (RAL) dengan faktor perlakuan pengeringan yang terdiri dari empat taraf perlakuan sebagai berikut : P1: pengeringan menggunakan oven (suhu $50^{\circ} \mathrm{C}$ selama 24 jam); P2: pengeringan menggunakan sinar matahari (suhu $\pm 40^{\circ} \mathrm{C}$ selama 3 hari); P3: pengeringan suhu ruang atau kering angin (suhu $\pm 26^{\circ} \mathrm{C}$ selama 6 hari); P4: pengeringan dengan cara disangrai (suhu $50^{\circ} \mathrm{C}$ selama 45 menit). Perlakuan di atas diulang sebanyak 4 kali sehingga diperoleh 16 unit percobaan.

\section{Pelaksanaan Penelitian}

\section{Pembuatan Bubuk Teh Herbal Celup Rimpang Temu Putih}

Proses pembuatan teh herbal celup rimpang temu putih merujuk pada penelitian yang telah dilakukan Felicia et al., (2018) yang telah dimodifikasi. Rimpang temu putih disortasi dengan kriteria tidak memiliki bopeng pada rimpangnya, dan dibersihkan dari sisa tanah yang masih menempel. Temu putih yang telah disortasi kemudian dicuci menggunakan air mengalir untuk membersihkan dari sisa tanah yang masih menempel, kemudian ditiriskan. Selanjutya temu putih dikupas dan dicuci kemudian di iris dengan ketebalan kurang lebih $2 \mathrm{~mm}$.

Proses selanjutnya yaitu pengeringan menggunakan beberapa perlakuan yang ditentukan yaitu, menggunakan oven, penggeringan sinar matahari, pengeringan suhu ruang atau kering angina, serta pengeringan dengan cara disangrai. Setelah dikeringkan selanjutnya dilakukan penggilingan menggunakan blender, lalu diayak menggunakan ayakan 40 mesh. Serbuk temu putih yang didapat kemudian dikemas ke dalam kantong teh celup dengan ketentuan masing-masing kantong teh berisi 2 gram serbuk temu putih. 
Pembuatan Seduhan Teh Herbal Celup Temu Putih

Pembuatan larutan teh untuk uji sensoris dilakukan dengan cara, satu kantong teh herbal celup temu putih dimasukkan ke dalam gelas, kemudian ditambahkan air bersuhu $100^{\circ} \mathrm{C}$ sebanyak $200 \mathrm{ml}$ dan diseduh selama 3 menit. Dalam waktu 3 menit, kantong teh celup digerakkan naik turun dalam air. Setelah itu, kantong teh celup dikeluarkan dari larutan dan larutan dibiarkan sampai bersuhu kamar $\left(26^{\circ} \mathrm{C}\right)$. Larutan diuji secara organoleptik (Horzic et al., 2009).

\section{Variabel yang Diamati}

Variabel yang diamati dalam penelitian ini adalah analisis karakteristik kimia menggunakan bubuk teh herbal temu putih secara kualitatif dan kuantitatif, serta analisis sensoris menggunakan air seduhan terh herbal temu putih yang di analisis secara skoring dan hedonik.

Analisis kualitatif kurkumin dilakukan berdasarkan (Rinanto et al., 2009 yang telah dimodifikasi), analisis kualitatif fenol (Harbone, 1987 yang telah dimodifikasi), analisis kualitatif flavonoid (Pratiwi et al., 2010 yang telah dimodifikasi), total kurkumin menggunakan metode curcumin sebagai standar berdasarkan (Harini et al., 2012), total fenol menggunakan metode Folin-ciocalteu berdasarkan (Sakanaka et al., 2003), total flavonoid menggunakan kolorimetri aluminium klorida berdasarkan ( $\mathrm{Xu}$ dan
Chang, 2007), dan analisis sensoris (Soekarto,1985).

\section{HASIL DAN PEMBAHASAN}

\section{Analisis Kualitatif Kurkumin, Fenol, dan Flavonoid}

Hasil analisis kualitatif terhadap kandungan kurkumin, fenol, dan flavonoid bubuk teh herbal celup temu putih dapat dilihat pada Tabel 1. Hasil analisis menunjukkan hasil positif pada masingmasing perlakuan pengeringan (menggunakan oven, sinar matahari, suhu ruang atau kering angin, dan dengan cara disangrai).

Pengeringan dengan menggunakan suhu ruang atau kering angin menghasilkan nilai rata-rata total kurkumin tertinggi yaitu sebesar 29,10 mg CE/g karena suhu yang digunakan rendah yaitu \pm 26 oC sehingga senyawa kurkumin di permukaan maupun di dalam bahan dapat dipertahankan meskipun membutuhkan waktu yang lebih lama. Menurut Tonnesen dan Karlsen (1985), kurkumin merupakan senyawa yang peka terhadap pengaruh $\mathrm{pH}$, suhu, cahaya, radikal, serta mudah mengalami degradasi sehingga pada suhu ruang senyawa kurkumin tidak rusak oleh panas. Proses pengeringan menggunakan suhu ruang dilakukan pada ruangan tertutup yang memiliki ventilasi sehingga senyawa kurkumin dalam bahan tidak terdegradasi oleh panas dan cahaya. Pengeringan dengan cara disangrai menghasilkan nilai rata-rata total kurkumin terendah yaitu sebesar 12,56 
mg CE/g, karena senyawa kurkumin dalam bahan terdegradasi oleh panas dari suhu yang diberikan. Green (2004), menyatakan bahwa kurkumin sangat terpengaruh oleh pemanasan. Proses pemanasan mengakibatkan proses oksidasi lebih cepat dan mengurangi kestabilan pada kurkumin. Adanya senyawa kurkumin pada bahan ditandai dengan adanya perubahan warna merah, senyawa fenol ditandai dengan perubahan warna menjadi hijau, serta adanya senyawa flavonoid ditandai dengan terbentuknya perubahan warna menjadi orange.

\section{Total Kurkumin}

Hasil analisis total kurkumin rata-rata bubuk teh herbal temu putih dapat dilihat pada Tabel 2. Hasil sidik ragam menunjukkan bahwa perbedaan pengeringan memberikan pengaruh sangat nyata $(\mathrm{P}<0,01)$ terhadap total kurkumin bubuk teh herbal temu putih.

Tabel 1. Hasil Analisis Kualitatif Bubuk Teh Herbal Celup Temu Putih

\begin{tabular}{|lllc|}
\hline Perlakuan & Kurkumin & Fenol & Flavonoid \\
\hline P1 (pengeringan oven suhu $50^{\circ} \mathrm{C}$ selama 24 jam) & + & + & + \\
P2 (pengeringan sinar matahari suhu $\pm 40^{\circ} \mathrm{C}$ selama 3 hari) & + & + & + \\
P3 (pengeringan suhu ruang atau kering angin suhu $\pm 26^{\circ} \mathrm{C}$ selama 6 & & & \\
hari) & + & + & + \\
P4 (pengeringan dengan cara disangrai suhu $50^{\circ} \mathrm{C}$ selama 45 menit) & + & & + \\
\hline
\end{tabular}

Tabel 2. Nilai rata-rata total kurkumin bubuk teh herbal temu putih (mg CE/g bubuk)

\begin{tabular}{lc}
\hline \multicolumn{1}{c}{ Perlakuan } & $\begin{array}{c}\text { Rata-rata Kadar } \\
\text { Kurkumin }(\mathrm{mg} / \mathrm{g})\end{array}$ \\
\hline P1 (pengeringan oven suhu $50^{\circ} \mathrm{C}$ selama 24 jam) & $15,13 \pm 0,38$ b \\
P2 (pengeringan sinar matahari suhu $\pm 40^{\circ} \mathrm{C}$ selama 3 hari) & $18,94 \pm 0,25 \quad \mathrm{c}$ \\
P3 (pengeringan suhu ruang atau kering angin suhu $\pm 26^{\circ} \mathrm{C}$ selama 6 hari) & $29,10 \pm 0,33 \quad \mathrm{~d}$ \\
P4 (pengeringan dengan cara disangrai suhu $50^{\circ} \mathrm{C}$ selama 45 menit) & $12,56 \pm 0,35 \quad$ a \\
\hline Keterangan: Nilai rata-rata yang diikuti huruf yang berbeda pada kolom sama menunjukkan pengaruh \\
yang sangat nyata $(\mathrm{P}<0,01)$
\end{tabular}

\section{Total Fenol}

Berdasarkan hasil sidik ragam menunjukkan bahwa perbedaan perlakuan pengeringan memberikan pengaruh sangat nyata $(\mathrm{P}<0,01)$ terhadap total fenol bubuk teh herbal temu putih. Hasil analisis total fenol dapat dilihat pada Tabel 3 
Pengeringan dengan menggunakan suhu ruang atau kering angin menghasilkan nilai rata-rata total fenol tertinggi yaitu sebesar 167,51 mg GAE/g, karena pada perlakuan tersebut memiliki suhu yang rendah dengan kelembapan yang tinggi sehingga dapat menghambat penguapan senyawa fenol. Ramma et al., (2002), menyatakan bahwa perbedaan kandungan fenol antara bahan segar dan kering disebabkan akibat proses pengeringan. Dalam kondisi suhu ruang $\left( \pm 25^{\circ} \mathrm{C}-27^{\circ} \mathrm{C}\right)$ senyawa fenol yang terdapat pada bahan dapat dipertahankan karena tidak terdegradasi oleh panas. Hal tersebut sesuai dengan pernyataan Chu dan Juneja (1997), menyatakan bahwa kadar total fenol meningkat dengan menurunnya suhu pengeringan karena fenol tersebut tidak mengalami penguapan yang disebabkan oleh pemanasan.
Nilai rata-rata total fenol terendah diperoleh dari perlakuan pengeringan dengan cara disangrai yaitu sebesar 119,13 mg GAE/g, dikarenakan senyawa fenol memiliki sifat mudah teroksidasi terhadap perlakuan panas, sehingga dengan adanya proses pengeringan dengan panas yang langsung mengenai bahan seperti dengan cara disangrai dapat menurunkan kandungan senyawa fenol. Pengeringan dengan cara disangrai memiliki kelemahan pada suhu yang dihasilkan oleh api kompor tidak konstan. Vatai et al., (2009), menyatakan bahwa kandungan senyawa fenolik sangat sensitif, tidak stabil, dan sangat rentan terhadap degradasi. Degradator paling utama adalah temperatur, kandungan oksigen, dan cahaya. Pemanasan dengan meningkatnya suhu pengeringan akan menyebabkan kerusakan sebagian besar senyawa fenolik (Tuminah, 2004).

Tabel 3. Nilai rata-rata total fenol bubuk teh herbal temu putih (mg GAE/g bubuk)

\begin{tabular}{lcc}
\hline \multicolumn{1}{c}{ Perlakuan } & $\begin{array}{c}\text { Rata-rata Kadar Fenol } \\
(\mathrm{mg} / \mathrm{g})\end{array}$ \\
\hline P1 (pengeringan oven suhu 50 $0^{\circ} \mathrm{C}$ selama 24 jam) & $131,94 \pm 0,53 \quad \mathrm{~b}$ \\
P2 (pengeringan sinar matahari suhu $\pm 40^{\circ} \mathrm{C}$ selama 3 hari) & $143,59 \pm 0,53 \quad \mathrm{c}$ \\
P3 (pengeringan suhu ruang atau kering angin suhu $\pm 26^{\circ} \mathrm{C}$ selama 6 hari) & $167,51 \pm 0,53 \quad \mathrm{~d}$ \\
P4 (pengeringan dengan cara disangrai suhu 50 ${ }^{\circ} \mathrm{C}$ selama 45 menit) & $119,13 \pm 0,57 \quad \mathrm{a}$ \\
\hline
\end{tabular}

Keterangan : Nilai rata-rata yang diikuti huruf yang berbeda pada kolom sama menunjukkan pengaruh yang sangat nyata $(\mathrm{P}<0,01)$

\section{Total Flavonoid}

Hasil analisis rata-rata total flavonoid bubuk teh herbal temu putih dapat dilihat pada Tabel 4. Hasil sidik ragam menunjukkan bahwa perbedaan perlakuan pengeringan memberikan pengaruh sangat nyata $(\mathrm{P}<0,01)$ terhadap total flavonoid bubuk teh herbal temu putih. 
Total flavonoid bubuk teh herbal temu putih tertinggi diperoleh dari perlakuan pengeringan suhu ruang atau kering angin yaitu sebesar 41,47 mg QE/g, karena sifat dari senyawa flavonoid tidak berbeda jauh dengan sifat senyawa fenol yaitu mudah rusak dalam proses pemanasan. Flavonoid merupakan golongan terbesar dari senyawa fenolik yang berperan sebagai senyawa antioksidan. Utomo et al., (2009) telah melakukan penelitian pada herba sambiloto dengan beberapa metode pengeringan, bahwa terdapat penurunan kadar flavonoid pada herba sambiloto karena pengaruh variasi temperatur pada saat pengeringan dan juga karena adanya proses memasak. Pengeringan dengan cara dianginkan atau dalam suhu ruang memiliki kadar total flavonoid terbesar karena pengeringan dengan cara tersebut tidak menggunakan panas secara langsung namun menggunakan suhu ruang, sehingga senyawa yang terkandung di dalam bahan tidak mudah terdegradasi, terurai, dan tidak mengalami penurunan.

Total flavonoid terendah diperoleh dari perlakuan pengeringan dengan cara disangrai yaitu sebesar 22,17 mg QE/g, hal tersebut dikarenakan pada proses penyangraian dengan menggunakan wajan mengakibatkan terjadinya perpindahan panas dari permukaan pemanas ke dalam bahan secara langsung dimungkinkan dapat merusak flavonoid. Menurut Sivetz (1963) dalam Indrasari (2017), bahwa faktor yang harus diperhatikan dalam penyangraian adalah suhu penyangraian dan pengadukan. Pengadukan harus dilakukan terus menerus selama penyangraian agar panas yang digunakan merata sehingga kematangan yang dihasilkan seragam. Metode pengeringan dengan cara disangrai memiliki penurunan dan peningkatan suhu yang tidak konstan sehingga dapat mengakibatkan senyawa metabolit sekunder (flavonoid) rusak.

Tabel 4. Nilai rata-rata total flavonoid bubuk teh herbal temu putih (mg QE/g bubuk)

\begin{tabular}{lc}
\hline \multicolumn{1}{c}{ Perlakuan } & $\begin{array}{c}\text { Rata-rata Kadar } \\
\text { Flavonoid } \\
(\mathrm{mg} / \mathrm{g})\end{array}$ \\
\hline P1 (pengeringan oven suhu $50^{\circ} \mathrm{C}$ selama 24 jam) & $24,94 \pm 0,58 \mathrm{~b}$ \\
P2 (pengeringan sinar matahari suhu $\pm 40^{\circ} \mathrm{C}$ selama 3 hari) & $26,82 \pm 0,47 \mathrm{c}$ \\
P3 (pengeringan suhu ruang atau kering angin suhu $\pm 26^{\circ} \mathrm{C}$ selama 6 hari) & $41,47 \pm 0,51 \mathrm{~d}$ \\
P4 (pengeringan dengan cara disangrai suhu $50^{\circ} \mathrm{C}$ selama 45 menit) & $22,17 \pm 0,58 \mathrm{a}$ \\
\hline
\end{tabular}

Keterangan : $\quad$ Nilai rata-rata yang diikuti huruf yang berbeda pada kolom sama menunjukkan pengaruh yang sangat nyata $(\mathrm{P}<0,01)$ 


\section{Sifat Sensori}

Warna

Hasil pengujian skoring dan hedonik warna teh herbal temu putih dapat dilihat pada Tabel 5. Hasil sidik ragam menunjukkan bahwa perlakuan pengeringan berpengaruh sangat nyata $(\mathrm{P}<0,01)$ terhadap warna seduhan teh herbal temu putih yang dilakukan dengan uji skoring, dan tidak berpengaruh nyata $(\mathrm{P}>0,05)$ pada pengujian hedonik.

Tabel 5 menunjukkan bahwa nilai rata-rata warna seduhan teh herbal celup temu putih dengan uji skoring berkisar antara 2,96 - 4,64 dengan kriteria warna kuning kecoklatan sampai kuning muda. Nilai rata-rata warna tertinggi dengan uji skoring diperoleh pada perlakuan P1 yaitu 4,64 dengan kriteria kuning muda yang tidak berbeda nyata dengan perlakuan P3, sedangkan nilai rata-rata terendah diperoleh pada perlakuan P4 yaitu 2,96 dengan kriteria kuning kecoklatan yang tidak berbeda nyata dengan perlakuan P2. Berdasarkan SNI 3836 (2013) dalam Sari (2015), warna seduhan pada seduhan teh yang baik adalah khas produk. Tabel 5 menunjukkan bahwa perlakuan pengeringan tidak berpengaruh nyata $(\mathrm{P}>0,05)$ terhadap warna seduhan teh herbal celup temu putih yang dilakukan dengan uji hedonik. Nilai rata-rata kesukaan panelis terhadap warna teh herbal temu putih dengan uji hedonik berkisar antara 3,28 3,64 dengan kriteria agak suka sampai suka.

Tabel 5. Hasil uji skoring dan hedonik warna seduhan teh herbal temu putih

\begin{tabular}{lrr}
\hline \multicolumn{1}{c}{ Perlakuan } & Uji Skoring & Uji Hedonik \\
\hline P1 (pengeringan oven suhu $50^{\circ} \mathrm{C}$ selama 24 jam) & $4,64 \pm 0,76 \mathrm{~b}$ & $3,44 \pm 0,96$ a \\
P2 (pengeringan sinar matahari suhu $\pm 40^{\circ} \mathrm{C}$ selama 3 hari) & $3,40 \pm 1,16 \mathrm{a}$ & $3,64 \pm 0,95 \mathrm{a}$ \\
P3 (pengeringan suhu ruang atau kering angin suhu $\pm 26{ }^{\circ} \mathrm{C}$ & $4,36 \pm 0,95 \mathrm{~b}$ & $3,56 \pm 1,00 \mathrm{a}$ \\
selama 6 hari) & & \\
P4 (pengeringan dengan cara disangrai suhu50 ${ }^{\circ} \mathrm{C}$ selama 45 & $2,96 \pm 1,34 \mathrm{a}$ & $3,28 \pm 0,84 \mathrm{a}$ \\
menit) &
\end{tabular}

Keterangan :

(uji skoring) : $5=$ kuning muda $; 4=$ kuning tua $; 3=$ kuning kecoklatan $; 2=$ coklat kekuningan; $1=$ coklat (uji hedonik) : $5=$ sangat suka; $4=$ suka $; 3=$ agak suka $; 2=$ tidak suka $; 1=$ sangat tidak suka

\section{Aroma}

Hasil pengujian skoring dan hedonik aroma teh herbal temu putih dapat dilihat pada Tabel 6. Hasil sidik ragam menunjukkan bahwa perlakuan pengeringan tidak berpengaruh nyata $(\mathrm{P}>0,05)$ terhadap aroma seduhan teh herbal temu putih pada pengujian skoring dan hedonik .

Tabel 6 menunjukkan bahwa nilai rata-rata uji skoring aroma seduhan teh herbal temu putih berkisar antara 3,72-3,96 dengan kriteria khas teh herbal temu putih, sedangkan nilai rata-rata kesukaan panelis 
terhadap aroma seduhan teh herbal temu putih dengan uji hedonik berkisar antara 3,20 - 3,64 dengan kriteria agak suka sampai suka. Menurut Fello (1988) dalam Anjarsari (2015), aroma dalam bahan makanan dapat ditimbulkan oleh beberapa komponen volatil, akan tetapi komponen volatif tersebut dapat hilang selama proses pengolahan terutama panas. Menurut Patin et al., 2018 menurunnya aroma khas pada suatu bahan herbal disebabkan adanya aktivitas enzim pada proses pemanasan yang menyebabkan terlepasnya berbagai senyawa volatil pada bahan, hal ini disebabkan karena rusaknya senyawa - senyawa aromatik pada proses pengeringan.

Tabel 6. Hasil uji skoring dan hedonik aroma seduhan teh herbal temu putih

\begin{tabular}{llc}
\hline \multicolumn{1}{c}{ Perlakuan } & Uji Skoring & Uji Hedonik \\
\hline P1 (pengeringan oven suhu $50^{\circ} \mathrm{C}$ selama 24 jam) & $3,84 \pm 0,94$ a & $3,56 \pm 0,82$ a \\
P2 (pengeringan sinar matahari suhu $\pm 40^{\circ} \mathrm{C}$ selama 3 hari) & $3,96 \pm 0,84$ a & $3,44 \pm 0,71 \mathrm{a}$ \\
P3 (pengeringan suhu ruang atau kering angin suhu $\pm 26^{\circ} \mathrm{C}$ & $3,92 \pm 0,81$ a & $3,64 \pm 0,90 \mathrm{a}$ \\
selama 6 hari) & & \\
P4 (pengeringan dengan cara disangrai suhu 50 ${ }^{\circ} \mathrm{C}$ selama 45 & $3,72 \pm 1,17$ a & $3,20 \pm 0,76$ a \\
menit)
\end{tabular}

Keterangan :

(uji skoring): $5=$ sangat khas teh herbal temu putih ; $4=$ khas teh herbal temu putih; $3=$ agak khas teh herbal temu putih ; 2 = tidak khas teh herbal temu putih; $1=$ sangat tidak khas teh herbal temu putih,

(uji hedonik) : $5=$ sangat suka; $4=$ suka $; 3=$ agak suka $; 2=$ tidak suka $; 1=$ sangat tidak suka

\section{Rasa}

Hasil analisis uji skoring dan hedonik terhadap rasa seduhan teh herbal temu putih yang dapat dilihat pada Tabel 7. Hasil sidik ragam menunjukkan bahwa perlakuan pengeringan tidak berpengaruh nyata terhadap rasa seduhan teh herbal temu putih yang diuji secara skoring dan hedonik. Berdasarkan Tabel 7, nilai rata-rata uji skoring terhadap rasa seduhan teh herbal temu putih berkisar antara 1,88 - 2,24 dengan kriteria pahit, nilai rata-rata kesukaan panelis terhadap rasa teh herbal temu putih dengan uji hedonik berkisar antara 2,36-2,72 dengan kriteria tidak suka sampai agak suka. Tingkat kesukaan panelis terhadap rasa dari teh herbal temu putih dipengaruhi oleh kandungan kurkumin yang tinggi pada bahan baku dan memiliki rasa pahit.

\section{Penerimaan Keseluruhan}

Hasil sidik ragam menunjukkan bahwa perlakuan pengeringan tidak berpengaruh nyata terhadap penerimaan keseluruhan seduhan teh herbal temu putih yang diuji secara hedonik. Hasil analisis uji hedonik penerimaan keseluruhan terhadap seduhan teh herbal temu putih dapat dilihat pada Tabel 8. 
Nilai rata-rata kesukaan panelis secara keseluruhan terhadap teh herbal temu putih dengan uji hedonik berkisar antara 2,72 - 3,16. Nilai rata-rata tertinggi diperoleh pada perlakuan P1 yaitu 3,16 dengan kriteria agak suka sedangkan nilai rata-rata terendah diperoleh pada perlakuan $\mathrm{P} 4$ yaitu 2,72 dengan kriteria agak suka. Hal tersebut menunjukkan bahwa panelis masih dapat menerima produk teh herbal temu putih dari segi warna, aroma, dan rasa teh herbal temu putih.

Tabel 7. Hasil uji skoring dan hedonik rasa teh herbal temu putih

\begin{tabular}{lll}
\hline \multicolumn{1}{c}{ Perlakuan } & Uji Skoring & Uji Hedonik \\
\hline P1 (pengeringan oven suhu $50^{\circ} \mathrm{C}$ selama 24 jam) & $2,16 \pm 0,99$ a & $2,72 \pm 0,68$ a \\
P2 (pengeringan sinar matahari suhu $\pm 40^{\circ} \mathrm{C}$ selama 3 hari) & $2,24 \pm 1,13$ a & $2,68 \pm 0,90 \mathrm{a}$ \\
P3 (pengeringan suhu ruang atau kering angin suhu $\pm 26^{\circ} \mathrm{C}$ & $2,04 \pm 0,98$ a & $2,48 \pm 0,82 \mathrm{a}$ \\
$\begin{array}{l}\text { selama 6 hari) } \\
\text { P4 (pengeringan dengan cara disangrai suhu 50 }{ }^{\circ} \mathrm{C} \text { selama 45 }\end{array}$ & $1,88 \pm 0,93$ a & $2,36 \pm 0,81 \mathrm{a}$ \\
menit) &
\end{tabular}

Keterangan :

(uji skoring) : $5=$ sangat tidak pahit; $4=$ tidak pahit ; $3=$ agak pahit ; $2=$ pahit ; $1=$ sangat pahit (uji hedonik) : $5=$ sangat suka; $4=$ suka $; 3=$ agak suka $; 2=$ tidak suka $; 1=$ sangat tidak suka

Tabel 8. Hasil uji hedonik penerimaan keseluruhan teh herbal temu putih

\begin{tabular}{lc}
\hline \multicolumn{1}{c}{ Perlakuan } & Uji Hedonik \\
\hline P1 (pengeringan oven suhu $50^{\circ} \mathrm{C}$ selama 24 jam) & 3,16 a \\
P2 (pengeringan sinar matahari suhu $\pm 40^{\circ} \mathrm{C}$ selama 3 hari) & 3,12 a \\
P3 (pengeringan suhu ruang atau kering angin suhu $\pm 26^{\circ} \mathrm{C}$ selama 6 & 3,08 a \\
hari) & 2,72 a \\
P4 (pengeringan dengan cara disangrai suhu $50^{\circ} \mathrm{C}$ selama 45 menit) & \\
\hline
\end{tabular}

Keterangan $: 5=$ sangat suka; $4=$ suka $; 3=$ agak suka $; 2=$ tidak suka $; 1=$ sangat tidak suka

\section{KESIMPULAN DAN SARAN}

\section{Kesimpulan}

Perlakuan pengeringan pada proses pengolahan teh herbal temu putih berpengaruh terhadap total kurkumin, total fenol, total flavonoid, dan warna (uji skoring) dan tidak berpengaruh terhadap aroma, rasa, dan penerimaan keseluruhan (uji skoring dan hedonik).
Perlakuan terbaik didapatkan pada pengeringan menggunakan kering angin atau suhu ruang dengan suhu $\pm 26^{\circ} \mathrm{C}$ dengan karakteristik total kurkumin 29,10 mg CE/g, total fenol 167,51 mg GAE/g, dan total flavonoid 41,47 mg QE/g. Adapun karakteristik air seduhan teh herbal yang dihasilkan yaitu dengan warna kuning tua dan disukai, aroma khas teh herbal temu 
putih dan disukai, rasa pahit dan biasa, dan penerimaan keseluruhan biasa.

\section{Saran}

Pengeringan rimpang temu putih yang baik dapat dilakukan pada suhu rendah $( \pm$ $26^{\circ} \mathrm{C}$ ) yaitu dengan cara di angin-anginkan karena dapat mengurangi terjadinya kerusakan atau penurunan senyawa bioaktif yang terkandung dalam bahan.

\section{DAFTAR PUSTAKA}

Akram, M., A.A.S. Uddin., K. Usmanghani., A. Hannan., E. Mohiuddin, dan M. Asif. 2010. Curcuma longa and curcumin. Rom J Biol Plant Biol 55(2).

Anjarsari, B. 2015. Pengaruh suhu dan lama pengeringan terhadap karakteristik the herbal daun katuk (Sauropus adrogynus L. Mer). Jurnal Fakultas Teknik. Universitas Pasundan.

Cesarika, E. dan Lailliyatus, S. 2018. Pengaruh metode pengeringan rimpang temulawak, temugiring, dan kunyit terhadap parameter non spesifik. Jurnal Farmasi. Akademi Farmasi Putera Malang.

Chu, D.C, dan L.R. Juneja. 1997. general chemical composition of green tea and its infusion chemistry and applications of green tea. CRC Press LLC. USA. hal 13-21.

Fitrayana, C. 2014. Pengaruh lama dan suhu pengeringan terhadap karakteristik teh herbal pare (Momordica Charantia L). Tugas Akhir. Universitas Pasundan Bandung.

Green, R.J. 2004. http://www.lib.ncsu.ed $\mathrm{u} /$ theses/available/etd-11242004075813/unrestricted/edt.pdf. Diakses pada 6 mei 2019.

Harini, B.W., D. Rini, dan W.W. Lucia. 2012. Aplikasi metode spektrofotometri visibel untuk mengukur kadar curcuminoid pada rimpang kunyit (curcuma domestica).
Prosiding Seminar Nasional Aplikasi Sains \& Teknologi (SNAST) Periode III. Universitas Sanata Dharma, Yogyakarta.

Horzic, D., D. Komes., A. Belscak., K.K. Ganic., D. Ivekovic, dan D. Karlovic. 2009. The composition of polyphenols and methylxanthines in teas and herbal infusions. Food Chemistry. 115(2): 441 -448 .

Indrasari, Y.R. 2017. Pegaruh metode pengeringan terhadap aktivitas antioksidan dan total fenol daun kersen (Muntingia calabura L.) dengan berbagai konsentrasi. Skripsi. Universitas Mecu Buana. Yogyakarta.

Jeong, S. M., S.Y Kim., D. R. Kim., S.C. Joe., K.C. Nam., D.U. Ahn., dan S.C. Lee. 2004. Effect of heat treatment on the antioxidant activity of extracts from citrus peels. J-Agric. Food Chem. 52:3389-3393

Kencana, E.D. 2015. Pengaruh suhu dan lama pengeringan terhadap karakteristik teh herbal daun katuk (Sauropus adrogynus L. Merr). Skripsi Fakultas Teknologi Pangan. Universitas Pasundan. Bandung.

Liang, OB., Y. Widjaja, dan S. Puspa. 1985. Beberapa aspek isolasi identifikasi, dan penggunaan komponen-komponen curcuma xanthorrhiza roxb. dan curcuma domestika val. Prosiding simposium nasional temulawak. Lembaga Penelitian Universitas Padjajaran. Vol. 2, No. 1.

Meilgaard, M.C., B.T. Carr, dan G.V. Civile. 2016. Sensory evaluation techniques. Tersedia dalam:https://trove.nla.gov.au/work/68 52188. Diakses pada 03Mei 2020.

Patin, E. W., M. A. Zaini, dan Y. Sulastri. 2018. Pengaruh variasi suhu pengeringan terhadap sifat fisiko kimia teh daun sambiloto (Andrographis paniculata). Pro Food (Jurnal Ilmu dan Teknologi Pangan). 4(1):251-258.

Ramma, A.L., T. Bahorun., M.A. Soobratte, dan O.I. Aruoma. 2002. Antioxidant activities of phenolic, proanthocyanidin, and flavonoid components in extract of cassia fistula. Agriculture Food Chemistry. 
Sakanaka, S., Y. Tachibana, dan Y. Okada. 2003. Preparation and antioxiant properties of extracts of japanese persimo leaf tea (kakinocha-cha). Food chemistry. 89:569-575.

Sari, E.K. 2015. Karakteristik teh herbal dari daun kacapiring (Gardenia jasminoides ellis) dengan perbedaan posisi daun dan lama pengeringan. Skripsi. Fakultas Pertanian Universitas Sriwijaya.

Setyani, W. dan Astuti, D.W. 2013. Perbandingan rendemen minyak atsiri rimpang temulawak (Curcuma xanthorrhiza Roxb.) yang dikeringkan dengan diangin-anginkan, panas matahari dan oven serta identifikasi secara kromatografi lapis tipis. Stifar. Semarang

Soekarto, S.T. 1985. Penelitian Organoleptik Untuk Industri Pangan dan Hasil Pertanian. Bharata Karya Aksara, Jakarta.

Tonnesen, H.H. dan J. Karlsen. 1985. Studies on curcumin and curcuminoids (VI. kinetics of cur-cumin degradation in aqueous solution). Untersuchung und Forschung 180, 402-404.

Tuminah, S. 2004. Teh (Camellia sinensis) Sebagai Salah Satu Sumber
Antioksidan. Cermin Dunia Kedokteran No. 144:5254.

Verma, A. A. 2014. Optimization and quality assessment of low calorie herbal tea sweetened with stevia (Stevia rebaudiana). Journal of Medical Research and Development. 3(2): 134137.

Winarno, F.G. 1997. Kimia pangan dan gizi. PT Gramedia Pustaka Utama. Jakarta.

Windono, T. dan P. Nani. 2002. Curcuma zedoaria (Bergius) roscoe. Kajian Pustaka Kandungan Kimia Dan Aktivitas Farmakologi. Fakultas Farmasi Universitas Surabaya. 2(1) : 110.

Xu, B.J, dan S.K.C. Chang. 2007. A comparative on phenolic profiles and antioxidant activities of legumes as affected by extraction solvents. Journal of food Science. 72(2):159-166.

Yudana, I.G.A. 2004. Mengenal ragam dan manfaat teh http://www.indomedia.com/intisari/19 98/teh.html. Diakses pada 13 Januari 2019. 